\title{
Entertainment and Recreation in the Classical World-Tourism Products
}

\author{
Jamal El-Harami ${ }^{1}$ \\ ${ }^{1}$ Hospitality and Tourism Management Department, Al-Zaytoonah University of Jordan, Jordan \\ Correspondence: Jamal El-Harami, Hospitality and Tourism Management Department, Al-Zaytoonah University \\ of Jordan, Jordan. E-mail: jelharami@hotmail.com
}

$\begin{aligned} & \text { Received: December 28, } 2014 \quad \text { Accepted: January 26, } 2015 \quad \text { Online Published: February 20, } 2015 \\ & \text { doi:10.5539/jms.v5n1p168 }\end{aligned}$ URL: http://dx.doi.org/10.5539/jms.v5n1p168

\begin{abstract}
The aim of this study is to examine important aspects of social life of Greek and Roman societies by tracing means and ways of entertainment, recreation and leisure. Such activities were essential to the lives of Greco-Roman people and government officials. They include many forms of sports practiced by athletes during the famous Greek Olympic Games. The main events are chariot racing, horseback riding, running, wrestling and others. The Greeks and Romans constructed various buildings to house other forms of leisure such as theaters, amphitheater, gymnasia, circuses, public baths, and dinning out. These establishments served as the most popular pastime for centuries. The study presents a descriptive analysis of forms of entertainment, recreation and leisure known in Greece and Rome. Such activities are considered among the fast grown products of tourism in the present time. People enjoyed entertainment then just like we do today.
\end{abstract}

Keywords: ancient, Greco-roman, leisure, recreation, sports, and tourism products

\section{Introduction}

Ancient Greece and Rome were the birthplace of many sorts of recreational, leisure and sports that influenced modern understanding of social entertainment in various countries in the world. The classical age (500-400 B.C.) was often described as the Golden Age of Greece. The Athenians took great interest in the arts, education and in athletics. This interest was reserved to wellborn, aristocratic noblemen, who are full citizens. Craftsmen, farmers and traders people were also citizens but had limited and less prestige. The wealthy and powerful citizens represented the Athenian ideal of the balanced man - a combined soldier, athlete, artist, statesman and philosopher. This ideal was strengthened through education and the various religious festivals, which occupied about seventy days of the year. Other forms of arts such as music, poetry, theater, gymnastics and athletic competition were combined in these sacred competitions (Sansone, 2003).

Children in Greece and Rome enjoyed toys, dolls, carts, skip ropes, kites and seesaws. Gymnastic and music were taught at the age of seven which included running and leaping, wrestling, throwing the javelin and discus, boxing, swimming and ball games.

The Athenian philosophers stressed the role of the unity of mind and body and the strong relationship of all forms of human qualities and skills.

Recreation, leisure and sports activities dominated the thoughts of city planners who were keen to reserve adequate provisions for parks and gardens, open-air theaters and gymnasiums, baths, exercise grounds and stadiums.

The Greek approach to leisure and play witnessed a gradual transition. In the beginning all citizens were expected to participate in sports and games, and the Olympic Games were restricted to free-born Greeks only. Later on the religious and cultural event of the Olympic Games and other festivals were weakened by athletic specialization, corruption and commercialism.

Ancient Rome adopted many of the Greek traditions known for centuries passed before the Roman state evolved. Roman arts, religions, education and sports were influenced by Greek experience. Roman citizens participated in sports and gymnastics, intended to keep the body strong and the spirit courageous. Numerous games held in connection with the worship of carious Roman gods later developed into annual festivals supported by public funds such as military triumphs celebrations held in honor of the god Jupiter. 
Roman children engaged in many sports and games and possessed toy carts, dolls and hobby horses. Young boys were taught various sports and exercises such as running and jumping, sword and spear play, wrestling and swimming and horseback riding. The Roman concept of the leisure was different from the Greeks. Although, the Latin words for "leisure" and "business" are otium and negotium, suggesting the same view of leisure as a positive value. The Roman supported play for utililarian rather than asthetic or spiritual reasons.

Roman city planners and builders included in their towns provisions for baths, open-air theaters, amphitheaters, forums for public assembles and stadiums. They developed buildings for gymnastic sport, modeled after the Greek palaestra and including wrestling rooms and conversation areas for philosophers.

Roman society was divided into four social levels: the senators, who were the richest, the curiae, who owned more than twenty-five acres of land and were office holders or tax collectors, the plebs, free common people, and the coloni, who were lower class tenants of the land. Gradually, since most of works were performed by: coloni and slaves it became necessary for Roman Emperors and senate to amuse and entertain the plebs, they did so with the doles of grain and with public games - in other words, "bread and circuses".

Number of public holidays during the year reached 159 in the first century A.D., ninety-three of which were devoted to games at public expense, including many new festivals in honor of national heroes and foreign victories. By 354 A.D. these public festivals reached two hundred public holidays each year, including one hundred and seventy-five days of games.

Entertainment became the central life activity of many citizens in the Roman Empire as leisure increased and the decline in military service need. Their daily routine was expressed in entertainment by exercise, bathing in large and comfortable establishments where they could eat, read, socialize and do business. A substantial amount of business on Rome was done in thermaes, as they were a place for people to relax and chat in both tranquility and mild privacy. Relaxing within the city of Rome was the campus next to the Tiber River. Young men from all over Rome used it due to being able to go and train, then wash off immediately after. Sports played there included fast racing, archery and wrestling (Naylor, 2012).

\subsection{Study Aims}

This study aims to investigate the most important aspects of social life in Ancient Greece and Rome as performed in sports, bathing and theater. These activities reflected aspects of how Greeks and Romans performed forms of recreation, entertainment and leisure. The goal of the study is to show the roots of sport, entertainment and leisure tourism as it is illustrated in archaeological evidences that still exist in many ancient Greco and Roman cities around the Mediterranean Sea.

\subsection{Study Importance}

Tourism is the leading industry in the world. Its products vary from one country to another. In some countries tourism recently became known and developed. Antiquities and ancient literary sources in Greece and Rome present huge evidence that show the origin of modern entertainment, recreation and leisure. The importance of the study demonstrates setting the stage of the ancient routes and origins of modern tourism products and how it was practiced in the Greco-Roman world. Social life was an essential part of the lives of inhabitants of Greece and Rome during the classical ages. Remains of buildings used for social, entertainment and recreation are seen in many cities in the Greco-Roman world, such as theatres, amphitheaters, both complexes and stadia. Many themes were depicted in arts such as vase and mural paintings, mosaics and work sculpture.

This topic is chosen to demonstrate that social tourism, entertainment, recreations were deeply rooted in ancient civilizations. In modern days, such as: archaeological sites are being used to entertain tourists by showing the ancient plays performed in theater stages, various types of sports practiced in stadia whether running, chariot racing and gladiators in amphitheaters.

These activities are considered rich and fascinating tourism products in ancient times and as well as in modern times, one has to realize the role of the modern Olympic Games as a tourism product and their social and economic impact. Many sports competitions are held all over the world where nations compete fiercely to hold such sports. Sport tourism is a major source of income where it generates jobs and improves the livelihood of many people. Other complexes, such as, theaters, baths and arenas attract large numbers of tourists in modern days from many parts of the world.

\subsection{Methodology}

The study uses descriptive methodology where it examines the well-illustrated archaeological reports, writings of ancient historians and modern scholars works concerning the forms and types of entertainment, recreation and 
leisure in the Greco-Roman world. The study will trace the origins of entertainment, recreation and leisure and compare it to what is known in modern times.

\subsection{Recreation, Leisure and Sports in Ancient Greece}

Historically, recreation, leisure and sports was most significantly founded and developed in the ancient Greek era.

The Greek belief system is what has majorly influences today's concepts, in that setting aside time to enjoy music, art and other activities performed during leisure time is a critical aspect of living a "good life" and is physically and spiritually thought to be a key to happiness. For example, the Olympics were developed to appreciate the gods and goddess, and concentrate on the art of maintaining a strong physical and mental form. The Romans also influenced today's perception of what leisure is supposed to be. They believed by bringing citizens together in stadiums to watch competitive battles of the gladiators, and even coordinate bread and circuses, would implement a positive vibe to distract them from revolting against the Roman Empire (Msthomas, 2010).

\subsection{Sorts of Recreation, Leisure and Sports}

Culture and social life of Greece is deeply rooted in the second millennium B.C. Homeric epics the Illiad and the Odessy enriched our knowledge about early history and mythology of the Greeks. So did later historians such as, Herodotus, Pausanias and many others who provided us with enormous descriptions of Greek daily life, religion, theater, sports, arts and etc. (Pindar, 1997; Pausanias, 1926; Sweet, 1987).

To understand sorts and types of recreations, leisure and sports which marked Greek civilization had known and demonstrated through various activities and practices we ought to examine well known themes and festivals such as, the ancient Olympic Games, gymnastics, palaestra, baths, hippodromes, etc. (Raymond, 2002).

\subsubsection{Ancient Olympic Games}

The Greeks gave the modern world the concept of the Olympic Games which is a showcase of ancient Greek sports that originated in 776 B.C. in Olympia, a valley near a city called Elis, Greece. These games were held for five days every fourth summer in the same place. They continued until the year 393 A.D. (when they were discontinued by the Emperor Theodosius I of Rome), and after a long cessation period inspired the modern Olympic games, which began in 1896 (Young, 2004; Sealey, 1976).

There are many different theories and myths that try to explain their beginning, but no definite answer. The most famous myth involves Heracles, who was at a race at Olympic and then decreed that the race should be re-enacted once every four years (Swaddling, 1999; Valavanis, 2004).

\subsubsection{Ancient Olympia Sports in Ancient Greek World}

Athletics and sports were as popular and significant in the ancient Greek world as they are today and so far an excellent introduction to its archaeology and history.

There were many different sports that were played in ancient Greece. Most of the cities that were a part of ancient Greece had gymnasiums that were open to the public. The people who lived there were very healthy and loved sports. A list of the sports that were played there would include running, wrestling, boxing, horseback riding, chariot racing, discus and javelin throwing and jumping. In 776 B.C., the very first Olympic Games were held in ancient Greece. 


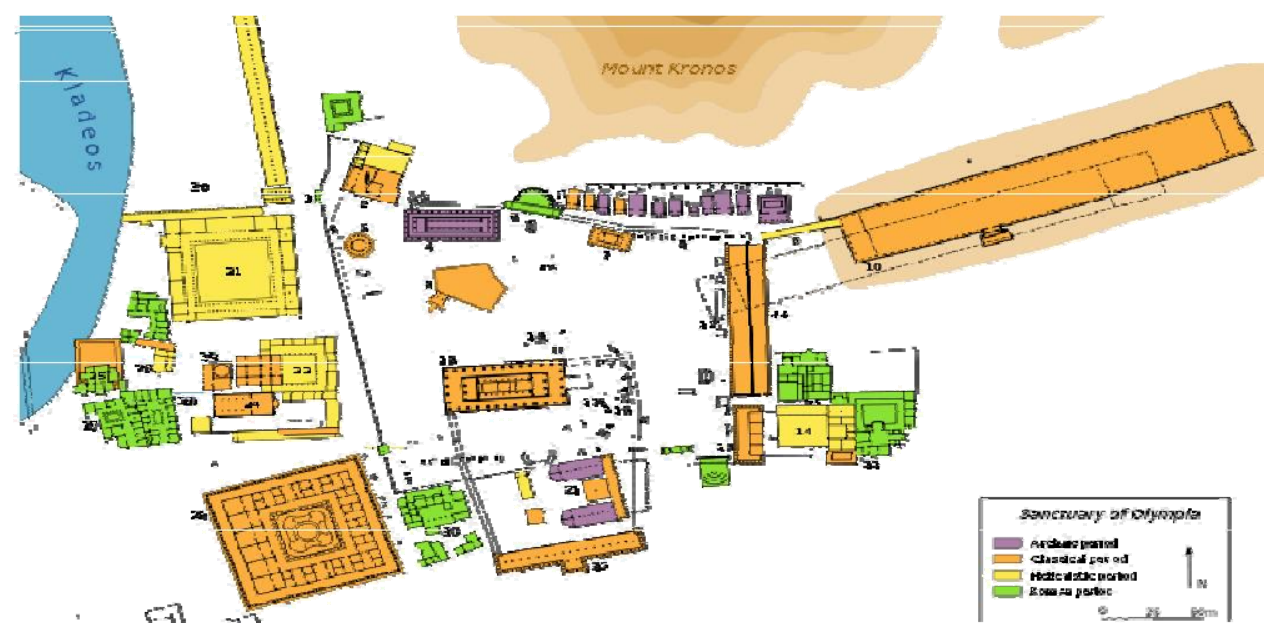

Source: Young.

Figure 1. Plan of Ancient Olympia, Greece

Who Played Sports in Ancient Greece?

Any citizen of Greece could participate in sporting events. They were considered a religious act during that time so it was a good way to display your faith in god or Zeus. (Scanlon, 2004).

All Greek city states were allowed to participate in these games and a truce was held among all Greek states where no wars or any form of fighting was permitted. These games were held in honor of Zeus. By the sixth century B.C., other Panhellenic (all Greek) games were being held at Delphi, such as the Pythian games which honored Apollo, the Nemean games at Nemea and held in honor of Zeus, the Ishmian games at Isthmia which celebrated Poseidon and at Olympia, they were dedicated to Zeus (Hemingway, 2000).

The victors of all these games brought honor to themselves, their families and their city-states. Public honors were given to them in various themes such as, dedicating statues, victory poems; numerous vases were decorated with scenes of competitions (Olympic Museums, 2007).

Sports in such games were aimed at setting records and excluded team competitions and performances. Contests included fast races, long jumps, diskos and javelin, wrestling, the pentathlon (a combination of these five events) boxing, the pankration (a combination of wrestling and boxing), horse races and chariot races. During competition and training, athletes were usually naked and rubbed with olive oil to keep off the dust. Only Greek citizens were allowed to compete in the games (Crowther, 2007).

Olympic Games were a Greek national festival that attracted artisans, dancers, singers, food stands and large numbers of spectators who cheered contestants and enjoyed themselves in many ways. The games period was a place full of recreation of many sorts. One can almost say that they were the originators of recreation and leisure. Every city-state had at least one gymnasium (Tomlinson, 2009).

\section{Gymnasium and Palaestra}

The concept of gymnasium originated in ancient Greece as a training facility for athletes competing in public games. The word "gymnasium" in Greek means "gymnastic school", which is derived from the common Greek adjective (gymnos) meaning "naked". The Greeks believed that human body is a symbol of beauty and should be taken care of and appreciated by regular exercises that athletes practiced and competed in the nude. This tradition demonstrated aesthetic appreciation of the male body. The gymnasium was also a place for socializing and engaging in intellectual pursuits. The athletic contests performed in the gymnasium formed part of the social and spiritual life of ancient Greeks. Gymnasium and palaestrae were under the protection and honor of heroes and gods. Archaeological works done over many years proved that gymnasiums were large structures containing provisions for each type of exercise as well as a stadium, palaestra, baths, outer porticos for practice in bad weather and covered porticos where philosophers delivered public lectures and held discussions (Dirk 1997).

The Greeks realized the strong relations between athletics, education and health. Physical training and maintenance of health and strength were major parts of education in early ages. 
Palestrae in origin served as school for physical training and became a part of the gymnasium where wrestling and boxing are included. The structural form of both facilities consisted of a colonnade surrounding an open space. In time both were subsumed within both complexes. This was a necessity and convience to have running tracks close to bathing facilities.

\section{Stadium}

The stadium is an open field designed for athletic games and other exhibitions with large seating capacity for spectators. The name stadium is derived from the Greek unit of measurement "stade" for distance covered in the original Greek races, which equals about six hundred feet. The shape of Greek stadium was long and narrow, which resembles a horseshoe (Lawrence, 1983).

The Greeks also built Hippodromes, which are similar to modern time in layout to stadiums but broad enough to accommodate four-horse chariot races. Seating areas from three sides that enable spectators to watch competitors during sport events surrounds the Hippodrome. The track measured at Olympia 212.54 meter long and 28.5 meter wide (Lawrence, 1983). Chariot racing was the most prestigious of the contests in the athletic festivals and took place in the hippodrome.

Ancient games played were running, horseback riding, chariot races, boxing, wrestling and the pentathion which a combination of five separate events. Discus, throwing, javelin, jump, running and wrestling. They were played in a similar way to modern day events.

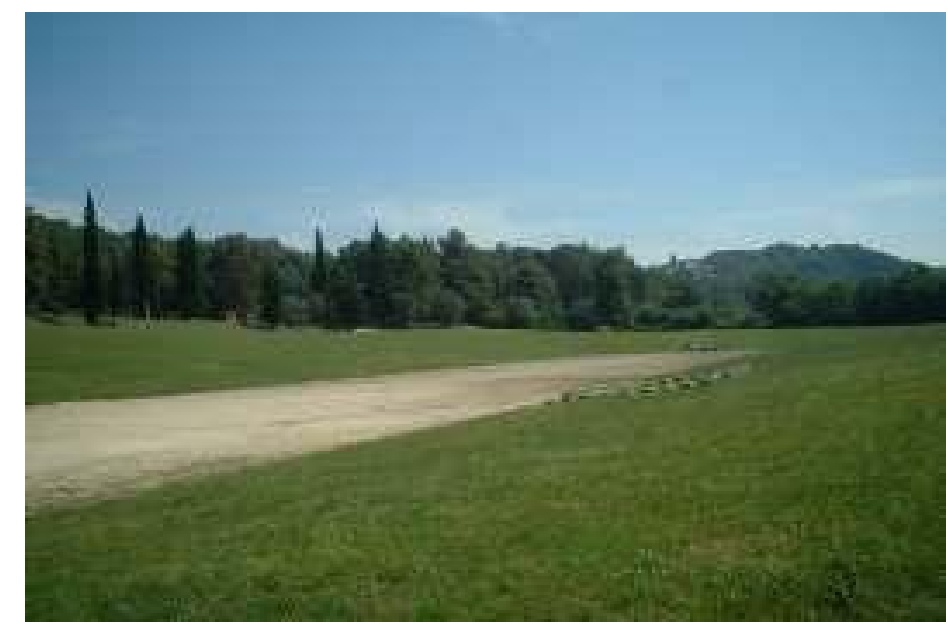

Source: Wikipedia.org-stadium

Figure 2. Olympia Stadium

\section{Greek Baths}

Ancient Greek understood the concept of bathing as a way of life. They considered that the bodily cleanliness was an essential component of good hygiene and good health. The Greek baths did not incorporate only the mere cleansing of the body, but also exercise and sports, socializing, lectures and entertainment and even snacks and sorts of food. Going to bathing facilities in any city was a great way to relax and chill and after a hard day's work.

Greek baths were not developed as Roman baths though the Greeks passed this concept to the Romans at a later time. Bathing was a communal affair in ancient times and different from now a day were homes have their own lavatory and bathing facilities. Visiting baths one would encounter strolling musicians, acrobats and jugglers offered entertainment.

Steam bath was called a Laconia, which is a circular room with a large, conical domed roof. Heating was caused by: fires underneath the floor (Lawrence, 1998).

\section{Greek Theater}

Theaters were an essential component of Greek's way of life, nearly every Greek city had an open-air theater and in some cases more than one. Here were ancient Greeks came for entertainment and leisure time. They sat and 
watched the famous plays of Aeschylus, Euripides, Aristophanes and Sophocles (Durury, 1971). The theater is a tradition very well known in Greek civilization since the sixth century B.C. Athenian comedy, tragedy and satyrs have been recorded as some of the earliest forms of theater to develop in the world and had a strong effect on the western culture and drama.

Greek theater history began with festivals performed to honor their gods such as Dionysus who is the Greek god of fertility and wine (Hemingway, 2004).

The shape of Greek theater basically remained the same where it was carved on the slope of a hill. It consisted of two main parts, the orchestra and skene "stage" on one side facing the auditorium, which is the seating area for the spectators. The orchestra was circular in shape as shown at the great theater of Epidaurus, which dates back to the year 330 B.C. Many ancient vases showed paintings on them depicting Greek comedy (Lawrence, 1983).

Theaters were located in areas close to the temples and Agora's "market places" which were very convenient to enable most people to attend theatrical plays. One can spend a day in this area where food was sold and musicians showed their skills.

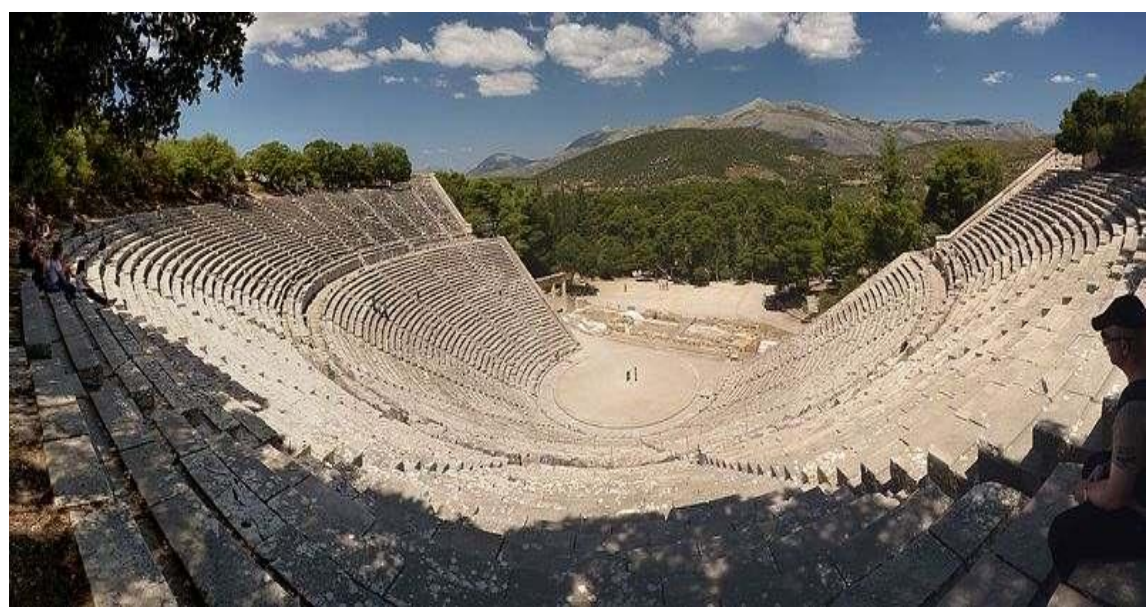

Source: Lawrence

Figure 3. Epidaurus Theater

\section{Entertainment, Recreations and Leisure in the Roman World}

The Romans fought many wars throughout early history, which resulted in their domination of many parts of Europe, Africa and Asia. During a time of wars and desire to rule the world, the Romans found time to engage in relaxing activities. They were able to do so due to the fact the slaves were working the entire year and were not permitted to attend public events. The Romans engaged in numerous activities in the area of entertainment. The wealthy population as well as the poor ones practiced these activities.

During the reign of Emperor Claudius the Romans had one hundred and fifty-nine days in the year were designated public holiday, ninety-three of which shows were offered at public expense. Entertainment and leisure were central to Roman life. This concept was demonstrated in various ways.

A. Theater developed in Rome under a large influence from the Greek's achievement in this respect whether in the architectural forms or well-known plays from the classical age of Greece. Plays were presented in theaters in Rome and many other Roman cities in the Empire. Emperor Pompey built a theater in Rome 55 B.C. that was large enough to accommodate twenty-seven thousand spectators. All actors in Roman plays were male slaves. The characters included the rich man, the king, the soldier, the slave, the young man and the young woman. Entrance to theaters was for free to citizens.

B. Romans demonstrated new achievements in the construction of amphitheaters "colosseum". A theater like oval in shape or elliptical most commonly used for gladiator matches. Several different types of shows all took place in the arena. The word arena is a Latin word which means "sand" which was placed on the amphitheater floor to soak up spitted blood. The majority of gladiators were criminals, slaves, prisoners of war or volunteers who chose to do the shows for a fee. Special types of "wild animal matches" were introduced in the second century B.C. Men on foot or horseback fought exotic animals. The first known amphitheater dates to 80 B.C. at 
Pompeii, the first permanent one in Rome goes back to twenty-nine B.C., which could accommodate up-to fifty thousand spectators.

Sloped seating for spectators was supported by vaulted masonry structures. Service corridors and chambers beneath the floor held animals until they were to go out onto the arena. In small towns the local amphitheater could be the only form of entertainment available (Olivova, 1989).

Entrance to the shows at the amphitheaters was usually free to the public. Roman emperors believed it was a good way to keep the people of Ancient Rome happy and content with their governors. The government provided free bread and free entertainment. By the first century B.C., magistrates used private games to gain support in elections, which was continued by emperors. Publically financed games also spread to the provinces.

What did the Romans see in amphitheaters? Specially trained slaves called Gladiators would fight each other. They would even fight wild animals such as lions or bears. When a gladiator lost a fight the audience would decide whether he should die or live. The audience would put their thumbs out if they wanted them to die. If they wanted them to live they kept their thumbs in their hands so they could not be seen.

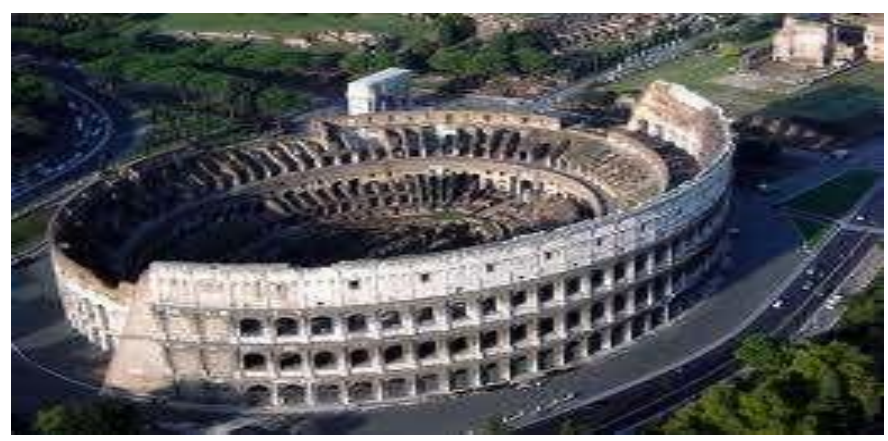

Source: Chase

Figure 4. Amphitheater Rome

C. Circus: Roman life revolved around work and business but still spared time off for leisure and entertainment. There were several activities to keep the people of Rome content and to prevent uprisings such as: chariot races at Circus Maximus a giant oval stadium in center of ancient Rome that seats two hundred thousand spectators in Rome. Chariot racing was the most popular pastime and the right place for those who seek to be entertained. As a sport it was extremely expensive and the most popular sport in Rome, appealing to all social classes from slaves to the emperor himself. There were four Roman racing companies or stables known by the racing colors worn by their charioteers, which are, red, white, blue and green.

These races were able to attract large numbers of fans who supported what could be called "club houses" in the same way in modern times were certain people are loyal to their favorite sports team. This partisanship was criticized in the first century A.D. by the Roman writer Pliny the Yunger (Harris 1972).

Races began with ceremonies with an elaborate procession headed by race sponsors follow by charioteers, musicians and dancers, priests carrying the statutes of the gods and goddesses who were to watch the races. There were twelve races per day doubled at a later date. 


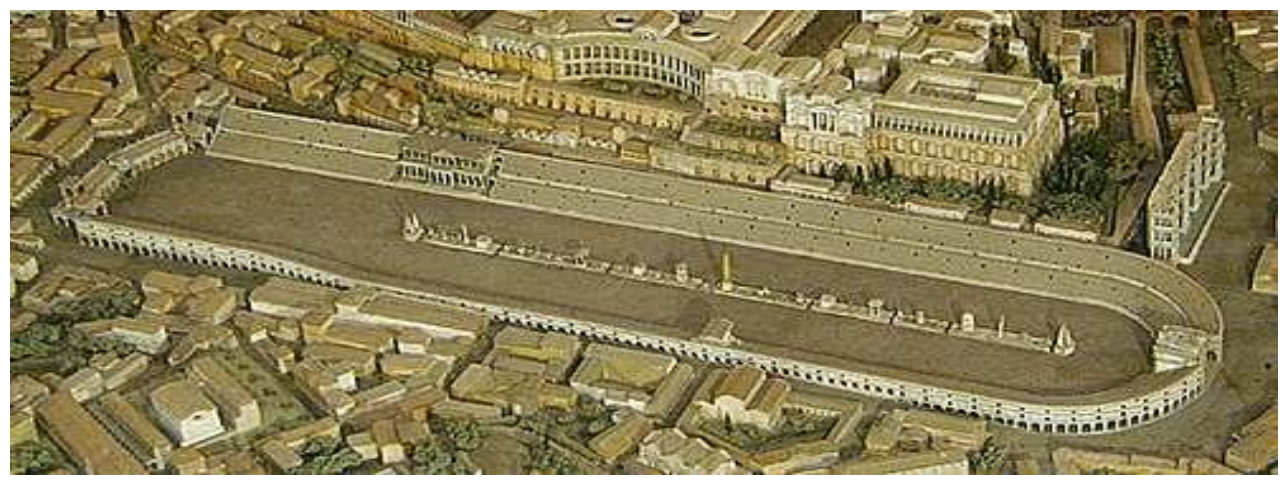

Source: Humphrey Circus Maximus

Figure 5. Circus Maximus

D. Sorts of Athletics Played in Roman Time: Athletics and forms of entertainment enjoyed by the Romans in ancient times were not much different from those that exist today include: horseback riding, swimming, wrestling and boxing, running, hunting and fishing, ball games and board games (McLellan, 1958; White, 1985).

E. Roman Baths: Bathing was a custom introduced to the Romans from ancient Greece by the end of the third century B.C. The Romans surpassed the Greek baths in building large bathing complexes known as thermae. They are demonstrated in Roman cities all over the empire. The Baths of Diocletian in Rome were the largest of the public baths, or thermae built by successive emperors. The baths were dedicated in 306 A.D. These baths could hold up to three thousand bathers (Yegul, 2010).

Bathing was one of the most common daily activities in Roman culture. Public baths served the urban communities of the Roman Empire. Steady growth in the popularity of baths in the first century B.C., followed by a sharper increase in the bathing habit in the early imperial period (Fagan, 1999). The archaeological evidence on the growth of the bathing habit centers on the public baths of Pompeii and the aqueducts water supply in Rome. Factors that contributed to the popularity of the baths were the Roman liked of bathing, communal life in Roman town, and private living quarters of the humble lacked amenities such as baths. Increasing luxury caused growth of bathing. Rising population in Rome contributed to a greater demand for baths. The concept of association of health reasons with bathing. Advances in building technology also benefited the popularity of the baths (Fagan, 1999).

The Romans did not go to bathing complexes to bathe only but also to meet with friends, socialize and exercise and pass a leisure time after a day of work much similar to spa goers in modern days. They considered baths a focal center for social and recreational activity. The baths included everyone such as: emperors, senators, equites, the elite, plebs, commoners and others of low station, including slaves as attendants and customers. Social mixing at the baths reflects aspects of social levelers in the Roman society. The baths contained places to eat, rest, play games and read. Entrances to baths were not free but it was quite cheap. Men and women bathed in separate baths.

Roman baths were different in size, arrangement and decoration. All Roman bathhouses contained a series of rooms got hot progressively hotter. They start in the following order:

A. Apodyterium, which is a room at the entrance where the bather changed and stored his clothes.

B. Frigidarium, the cold room that consisted of a pool, it was believed to have also been a social room.

C. Tepidarium, which is a warm room.

D. Caldarium, a room used for hot-water bath or for saunas or steam room. A brazier underneath the hollow floor, contained cold-water basins that the bather could use for cooling it.

E. Laconium, a dry resting room where the bather completes his bath ritual by resting (Humphrey 1986). 


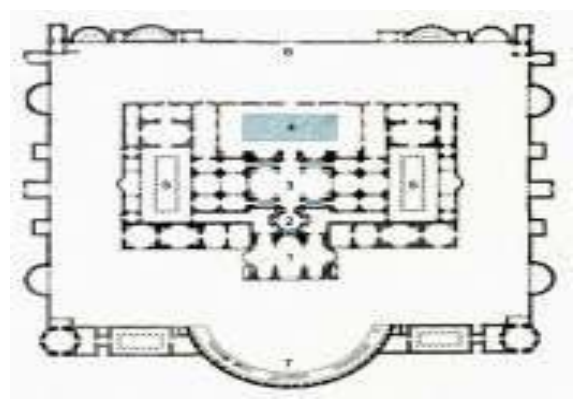

Source: Perkins

Figure 6. Diocleitian baths

The visitor to the baths would spend some of his time in each room according to his need. A large bathing complex would also contain an exercise area (plaestra), a swimming pool and gymnasium.

The building of a bath complex required excellent engineering skills. Baths needed a way of heating up water, which was done by using a furnace, and the hypocaust system carried the heat around the complex, a water supply system. In Rome this was done using 640 kilometers of aqua ducts (http://www.history/earningsite.co.uk/romanbaths.htm).

Roman baths offered amenities in addition to bathing ritual. Spaces were allocated to house food and perfume selling booths, libraries and reading rooms. Stages accommodated theatrical and musical performances, (Ancient Roman bathing - Wikipedia, the free encyclopedia).

\section{Conclusion: Greco-Roman Tourism Products}

The sequence of events and celebrations during the ancient Greek Olympics required a great deal of meticulous preparations. Greek athletes of various sports, city state officials who came to attend and honor winners, citizens who travelled from far away distances and sales people who set up vending stands or booths all brought to the Olympic site, which made Olympia appear as a grand festival.

All the attendants were in need of adequate accommodation and proper facilities to serve food and beverage. Visitors during the Olympic Games did not end their visit with the closing of sport competitions. They took their time to visit Greek temples in the vicinity such as the temples of Zeus and Hera (Sinn, 2000).

The movement of hordes of people from their hometowns tofar away places such as in the Olympic games defines sport events and festivals as a tourism product as we know it in modern times. Sports tourism is a fast growing tourism product as seen in many destinations in the world where many countries enter in fierce market competitions in order to have their countries win holding the sport events. In modern times sports increases tourism receipts.

Many sorts of entertainment and leisure in the Greek and Roman world existed as has been discussed in this paper. They covered various sectors such as theaters, bathing complexes, amphitheaters or colossiums as known in Rome and Pompeii and chariot racing, running, jumping, javelin and many others.

Attending such activities was done for the sake of entertainment and leisure. Roman Emperors paid for entrances to some of these events and festivals. The surrounding yards of baths and circuses constituted on a large open market where one could have seen merchants selling materials needed for bathing such as oil and strigils. Musicians play music to entertain people in their ways to such events. In this respect, it is obvious that entertainment, leisure and sports were central in the ancient daily lives of the Greeks and Romans and were very active and rich with different themes which continued in our daily lives in modern times, some of which did not change very much. Roman baths complexes laid the foundation of the leisure concept. Besides keeping the Romans clean, the baths provided a space for many other cultural and social activities. Baths reflected a balance between the body and the mind, many baths allocated space for leisure halls and libraries. Baths were places for friends and neighbors to meet and socialize which resulted in building community among the Romans. Since entrance to baths was so cheap, all classes of Roman society could enjoy them side by side in a classless environment. Even though politicians and the very wealthy had their own private baths in their living quarters they joined common people in the baths. The wide spread use of Roman baths in most cities of the Roman Empire indicates a high standard of living and rich culture. 
In modern time the ancient Olympic site of Olympia in Greece is a major tourism attraction where visitors are eager to see such well-known place. Greek plays from the classical period are enacted in ancient theaters such Epidaurus and Athens. These plays are considered a great entertainment for tourists since they are played at night. In Rome and many cities of the Roman Empire circuses and amphitheaters are used to display chariot racing and other sports for tourists. Grand festivals are held in ancient sites such as Jerash in Jordan, Baalbek in Lebanon and Carthage in Tunis. These sites and many others became fast growing tourism products in Greece, and the Mediterranean. The innovation in this research is shown by the events, such as kinds of sports, theatre, baths, practiced by the Greeks and the Romans which which proof that these were types and products of entertainement, recreation and leisure which are considered the origins of tourism procducts in the modern tourism industry. Classical writers left us several books, which contain detailed decriptions of these events and what they meant and required. State ertroganizes means of travel, accommodation, food and entertainment sports, health resorts, and health clubs, cultural events constitute main tourism products which are also major componenets of modern world tourism industry as well.

The long history of such tourism products was behind improving knowledge and understanding of tourism and leisure in modern times.

\section{References}

Bennet, D. (1997). Chariot Racing in the Ancient World. History Today (Britain), 47(12), 41-48.

Chase, R. G. (2002). Ancient Hellenistic and Roman Amphitheaters, Stadiums, and Theatres, The Way They Look Now. Peter E. Randall Publisher, Portsmouth, New Hampshire.

Crowther, N. B. (2007). The Ancient Olympic Games. Sport in Ancient Times. Greenwood Publishing Group.

Drury, V. (1971). The World of the Greeks. Geneva.

Fikret, Y. (2010). Bathing in the Roman World. Cambridge University Press.

Garrett, F. G. (2002). Bathing in Public in the Roman World. Ann Arbor, University of Michigan Press.

Golden, M. (2009). Helpers, Horses and Heroes. Greek Sport and Social Status. University of Texas Press.

Harris, H. A. (1972). Translated by William Melmoth, Sport in Greece and Rome. Ithaca: Corne II Press.

Humphrey, J. H. (1986). Roman Circuses, Arenas for Chariot Racing. University of California Press, Berkeley.

Kyle, D. (2007). Sport and Spectacle in the ancient world. Blackwell publishing, New York.

Lawrence, A. W. (1983). Greek Architecture. Penguin Books Ltd., Harmondsworth, Middlesex, England.

Mahoney, A. (2001). Roman Sports and Spectacles. A Source Book Focus Publishing, Newburyport, MA.

McLellan, M. C. (1985). To Play Properly with a Glass Ball. Expedition, 27(2), 41-43.

Miller, S. G. (2006). Ancient Greek Athletics. New Haven, Yale University, 92-95.

Olivova, J. (1989). Chariot Racing in the Ancient World. Nikephoros, 2, 65-88.

Osborne, R. (2004). Studies in Ancient Greek and Roman Society. Cambridge University Press.

Percy, D. B., \& Vyvian, J. (1974). Life and Leisure in Ancient Rome (2nd ed.). Bradley Head, University of Michigan.

Perkins, J., \& Ward, B. (1990). Roman Imperial Architecture, The Pelican History of Art (2nd ed.).

Rolf, J. (2000). Amphitheater (Rome). The Power of Spectacle in Ancient Rome, Gladiators and Caesars. University of California Press, Berkeley.

Romano, D. G. (1993). Athletics and Mathematics in Archaic Corinth: The Origins of the Greek Stadium. American Philosophical Society.

Sansone, D. (2003). Ancient Greek Civilization. Wiley-Blackwell.

Sealy, R. (1976). A History of the Greek City States 700-338 B.C. University of California Press, Los Angeles, California.

Spivey, N. J. (2004). Olympia: The Origins. The Fifth Century B.C. Oxford University Press.

Swaddling, J. (2008). The Ancient Olympic Games. British Museum Press.

Sweet, W. E. (1987). Sport and Recreation in Ancient Greece. Oxford University Press Oxford, England.

Tomlinson, A. (2005). Sport and leisure cultures. Minneapolis, MN: University of Minnesota Press. 
Ulrich, S. (2000). Olympia, Cult, Sport, and Ancient Festival. Markus Wiener Publishers, Princeton.

Valavanis, P. (2004). Games and Sanctuaries in Ancient Greece, Olympia, Delphi, Isthmia, Nemea, Athens. The J. Paul Getty Museum, Los Angeles.

Welch, K. E. (2007). The Roman Amphitheater from its Origins to the Coloseum. Cambridge University Press.

Wendy, J. R. (1988). Archaeology of the Olympics: The Olympics and other Festivals in Antiquity. University of Wisconsin Press.

White, D. (1985). Roman Athletics. Expedition, 27(2), 30-40.

Yegiil, F. (1992). Baths and Bathing in Classical Antiquity. Cambridge, MA, MIT Press.

Young, D. (2008). A Brief History of the Olympic Games. John Wiley \& Sons, p. 135.

\section{Copyrights}

Copyright for this article is retained by the author(s), with first publication rights granted to the journal.

This is an open-access article distributed under the terms and conditions of the Creative Commons Attribution license (http://creativecommons.org/licenses/by/3.0/). 